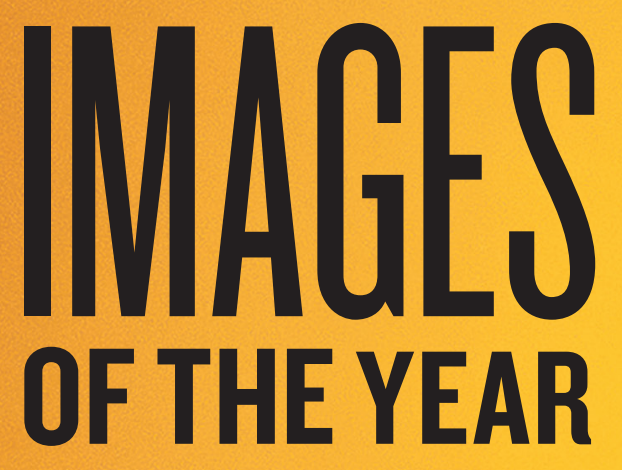

2018 will go down in history as a scorcher: deadly wildfires and droughts raged from California to Cape Town. The year also brought advances in cloning and imaging - and a bleak reminder of the fragility of some of Earth's rarest species. Here are the striking shots from science and the natural world that caught the eyes of Nature's editors.

Images selected by Nature's art editors

Text by Mico Tatalovic

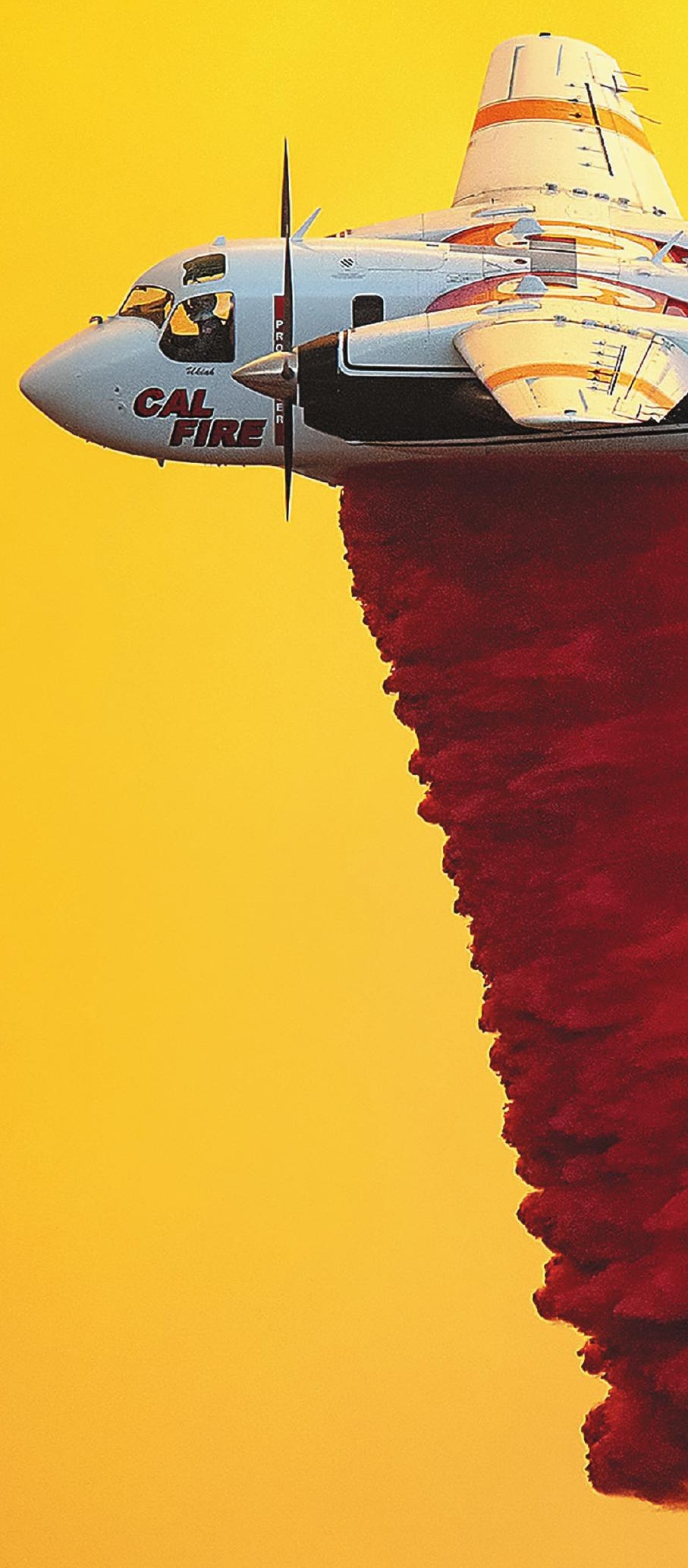




\section{EXTREME DOWNSIZING}

In May, a team at the Femto-ST Institute in Besançon, France, used nanoassembly tools - a focused ion beam, a gas-injection system and a tiny, manoeuvrable robot - to build this 20-micrometre-long house from silica.

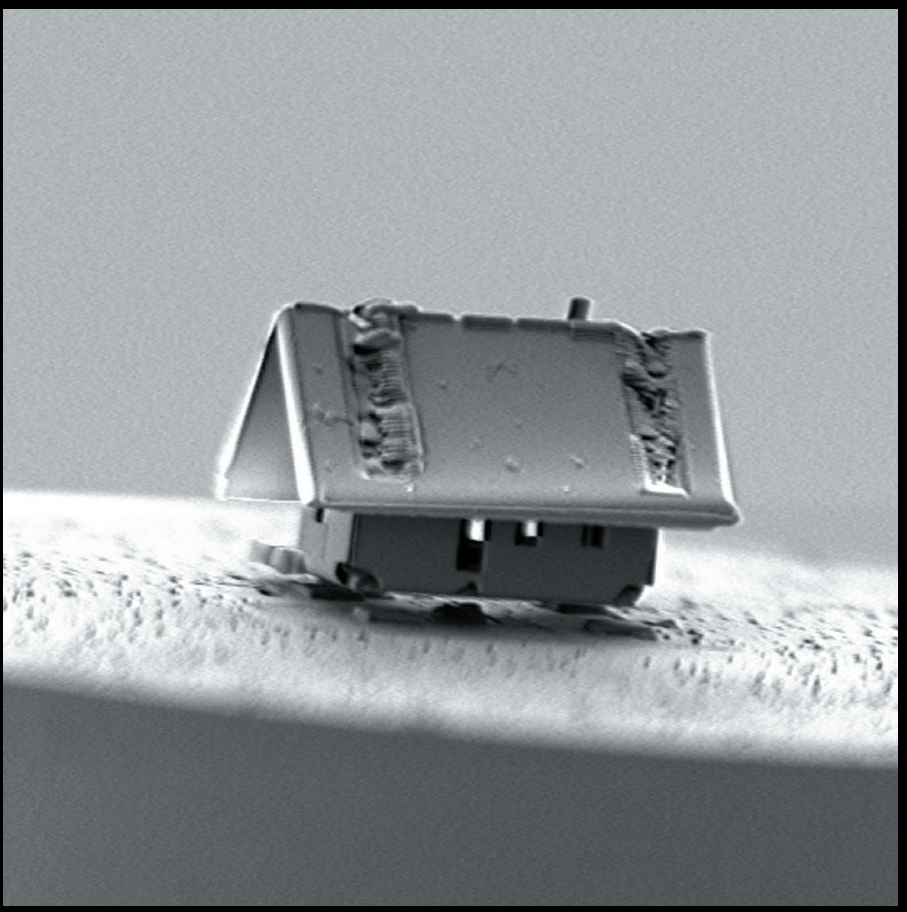

\section{SOUND SYSTEM}

Cell biologists Stephen Freeman and Laurence Delacroix at Liège University in Belgium won distinction in the Nikon Small World Photomicrography Competition with this image of neurons in a mouse's inner ear. The neurons are cultured in vitro to study how neurons mature and become damaged.

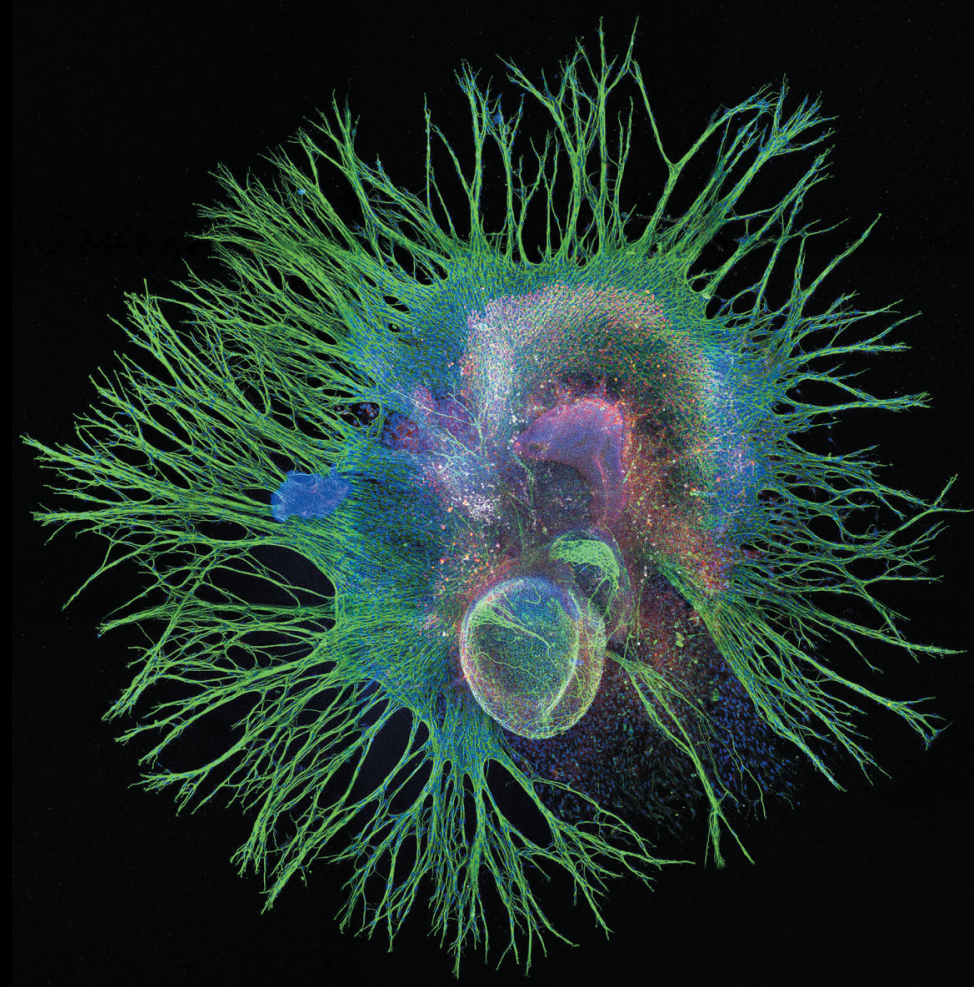

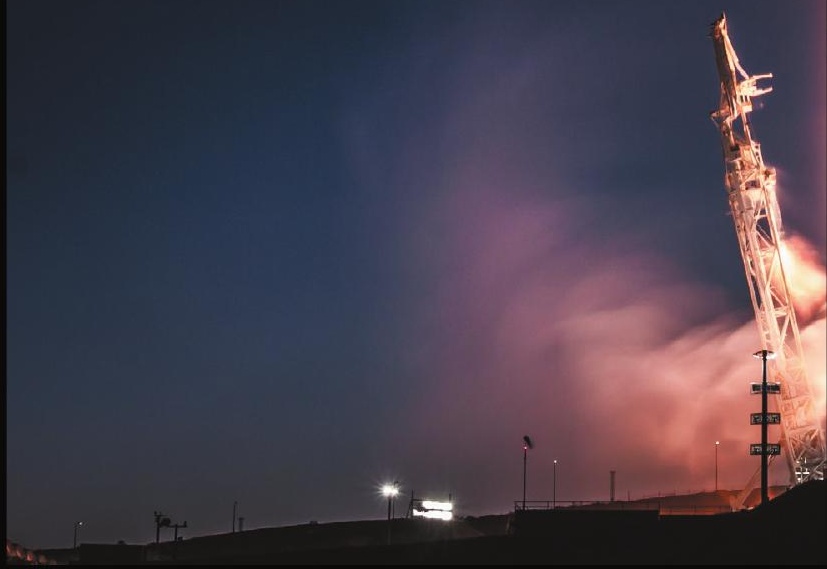

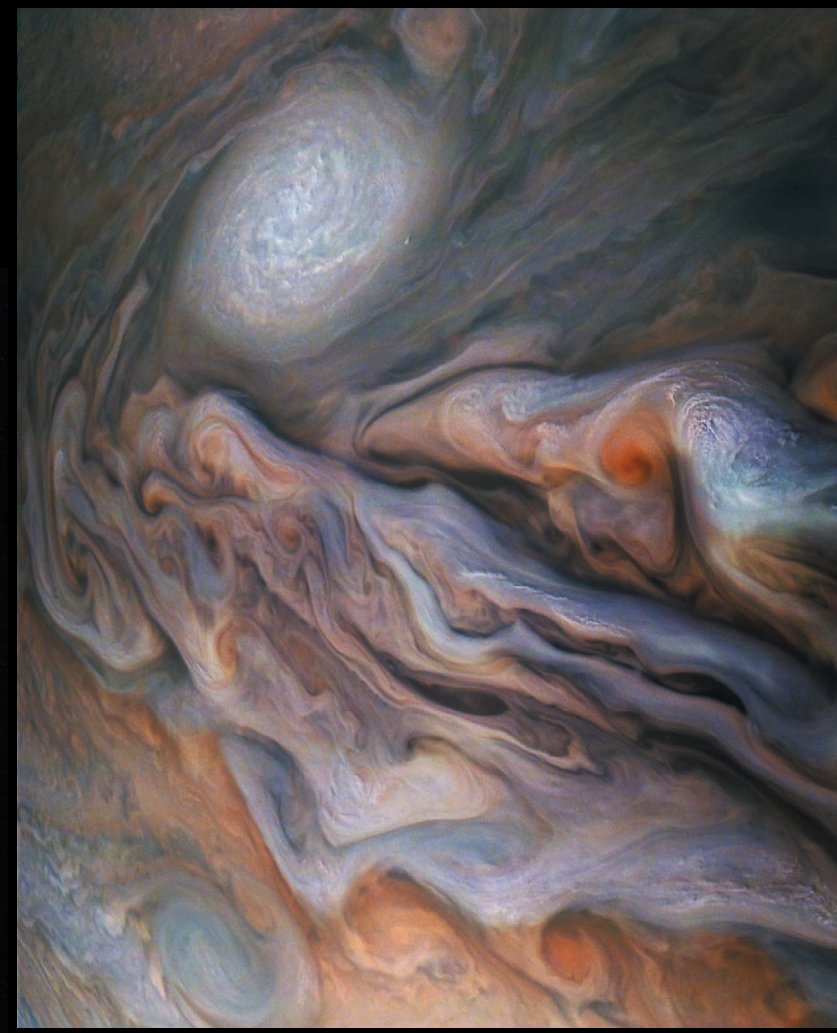

\section{STORM AND SWIRL}

NASA's Juno spacecraft, now in the eighth year of its mission to Jupiter, offered rich data and spectacular images of the gas giant. Swirling clouds and a large storm - the white oval are seen here in the planet's dynamic northern hemisphere. 
THE SCORCHED STATE

California's wildfires - some of the state's largest on record dominated headlines in 2018. Here, an aeroplane drops fire retardant in an area north of San Francisco in August. Authorities evacuated thousands of people.

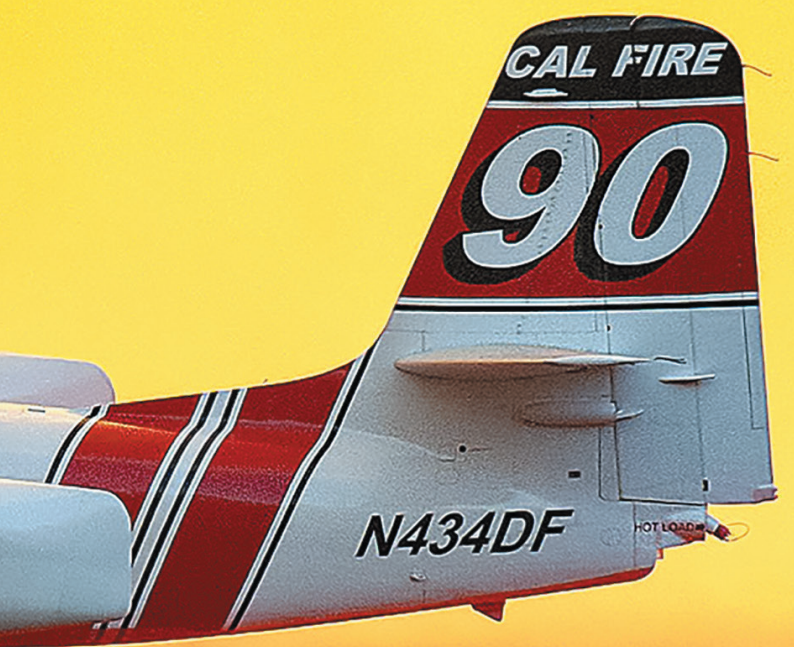




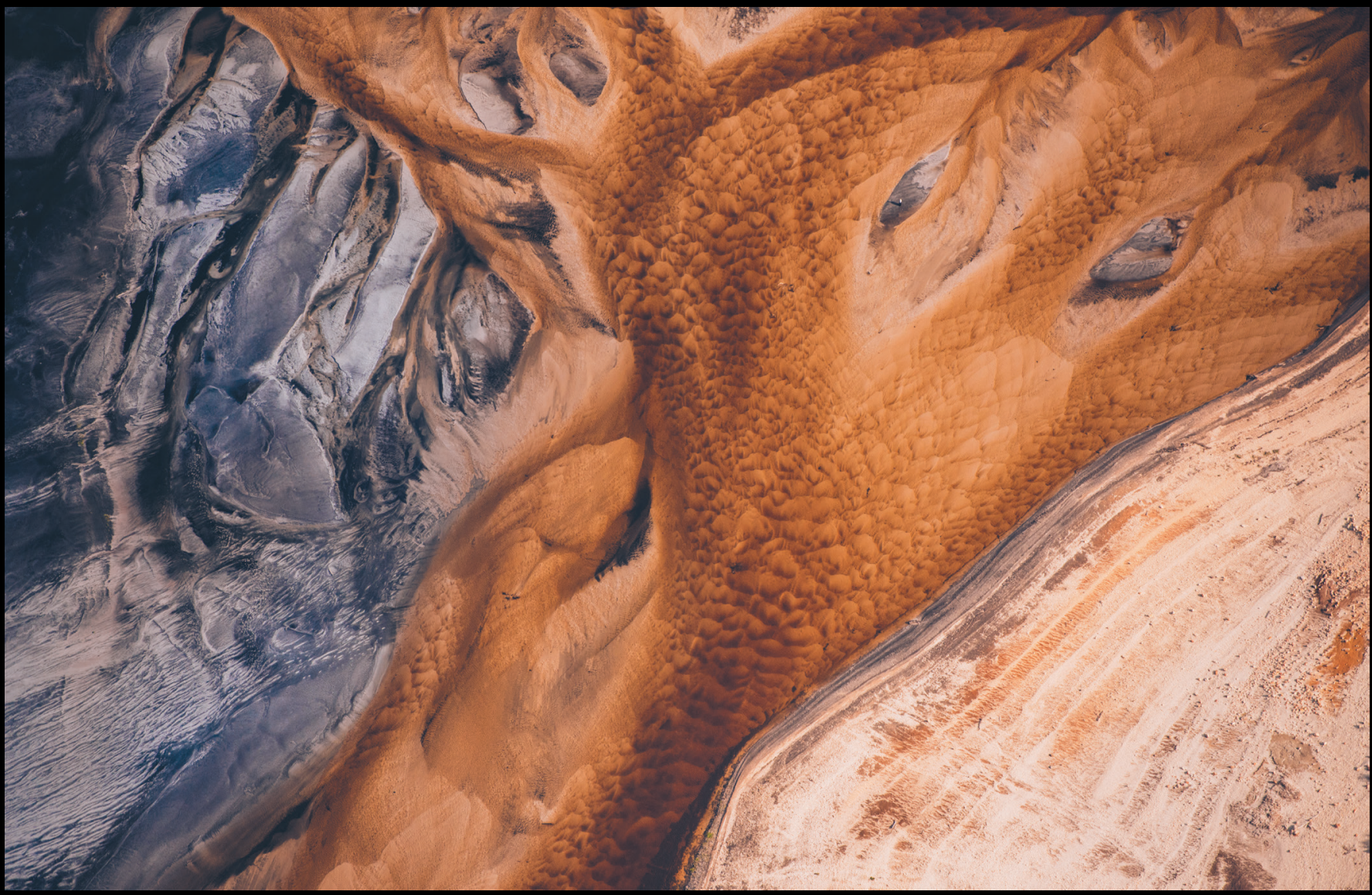

\section{SOUTH AFRICA'S CRIPPLING DROUGHT}

Three years of record-breaking drought in South Africa prompted officials in Cape Town to consider a dramatic move: shutting off taps completely. City resident and photographer Kelvin Trautman captured the scale of the crisis in this image of an empty reservoir at Steenbras Upper Dam.

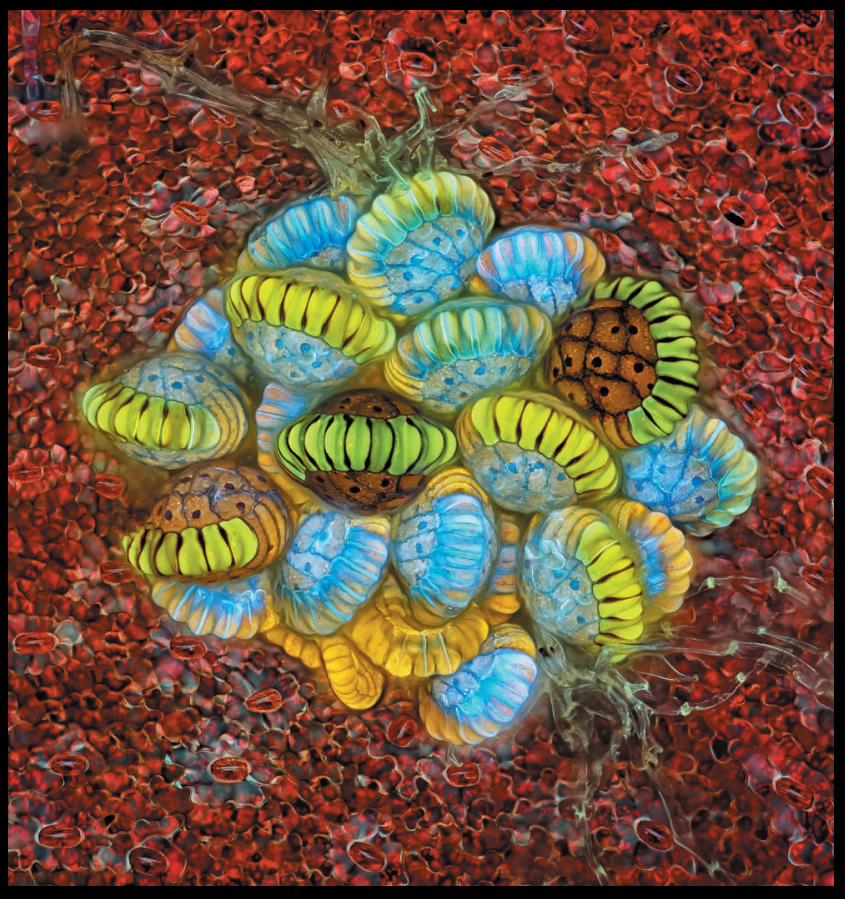

\section{SMALL-WORLD SPORES}

This 10x-magnified ultraviolet image of a fern sorus - the structure that produces and contains the plant's spores - won Rogelio Moreno Gill second place in the Nikon Small World Photomicrography Competition.

\section{TWO OF A KIND}

Meet Zhong Zhong and Hua Hua. The macaque twins, introduced to the world by Chinese researchers in January, were the first primates to be born using a cloning technique similar to that used to produce Dolly the sheep. Primates had proved difficult to copy using standard techniques.

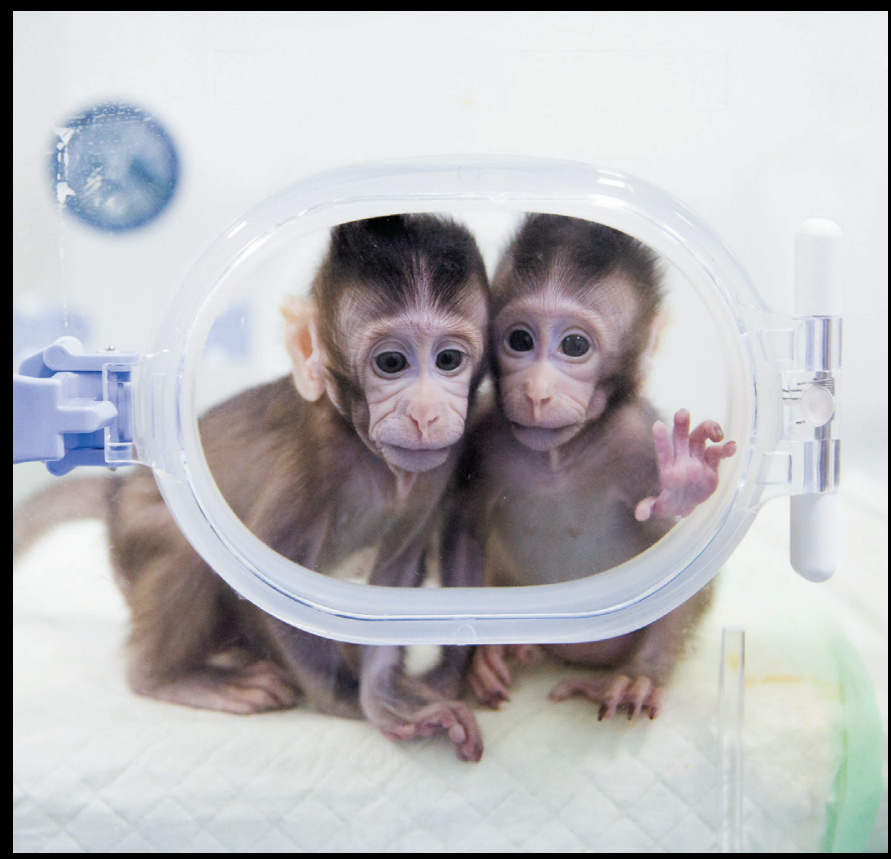




\section{GIANT GENOME}

A newly discovered giant Tupanvirus, found in amoebae, has both the longest tail and the largest set of genes involved in proteinmaking of any known virus.

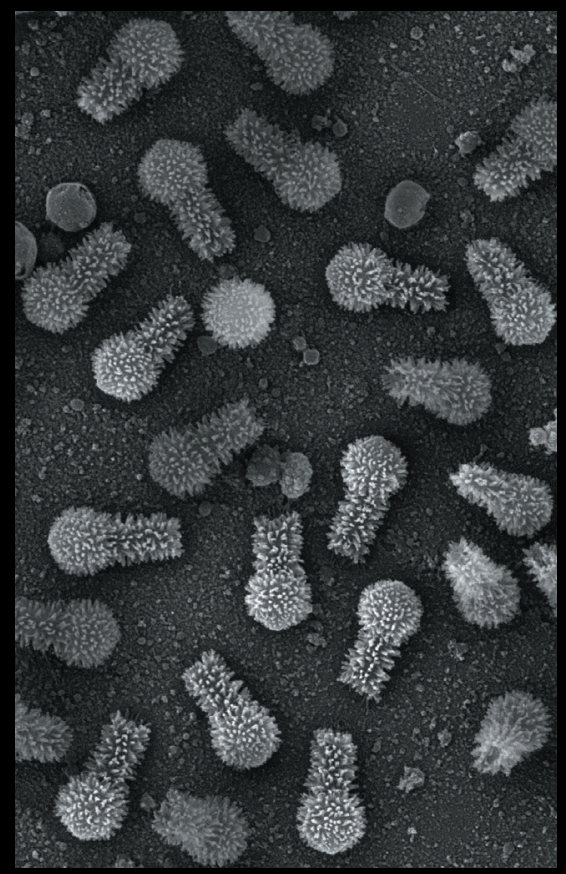

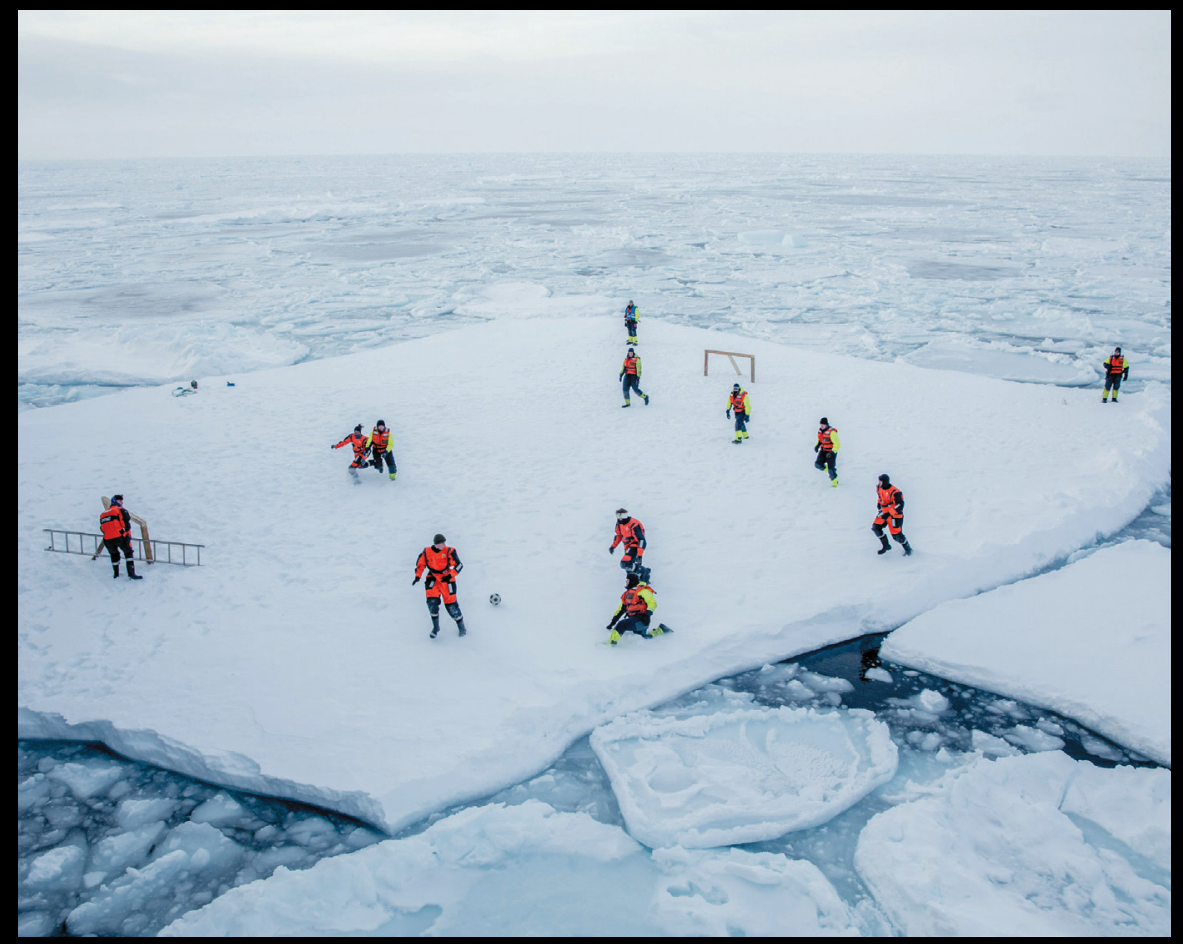

\section{WARMING UP}

An Arctic game of football is a risky business. During a match in March on an ice floe near Greenland, armed guards watched for polar bears while scientists from Norway's Institute of Marine Research and crew from a naval ice-breaker played.

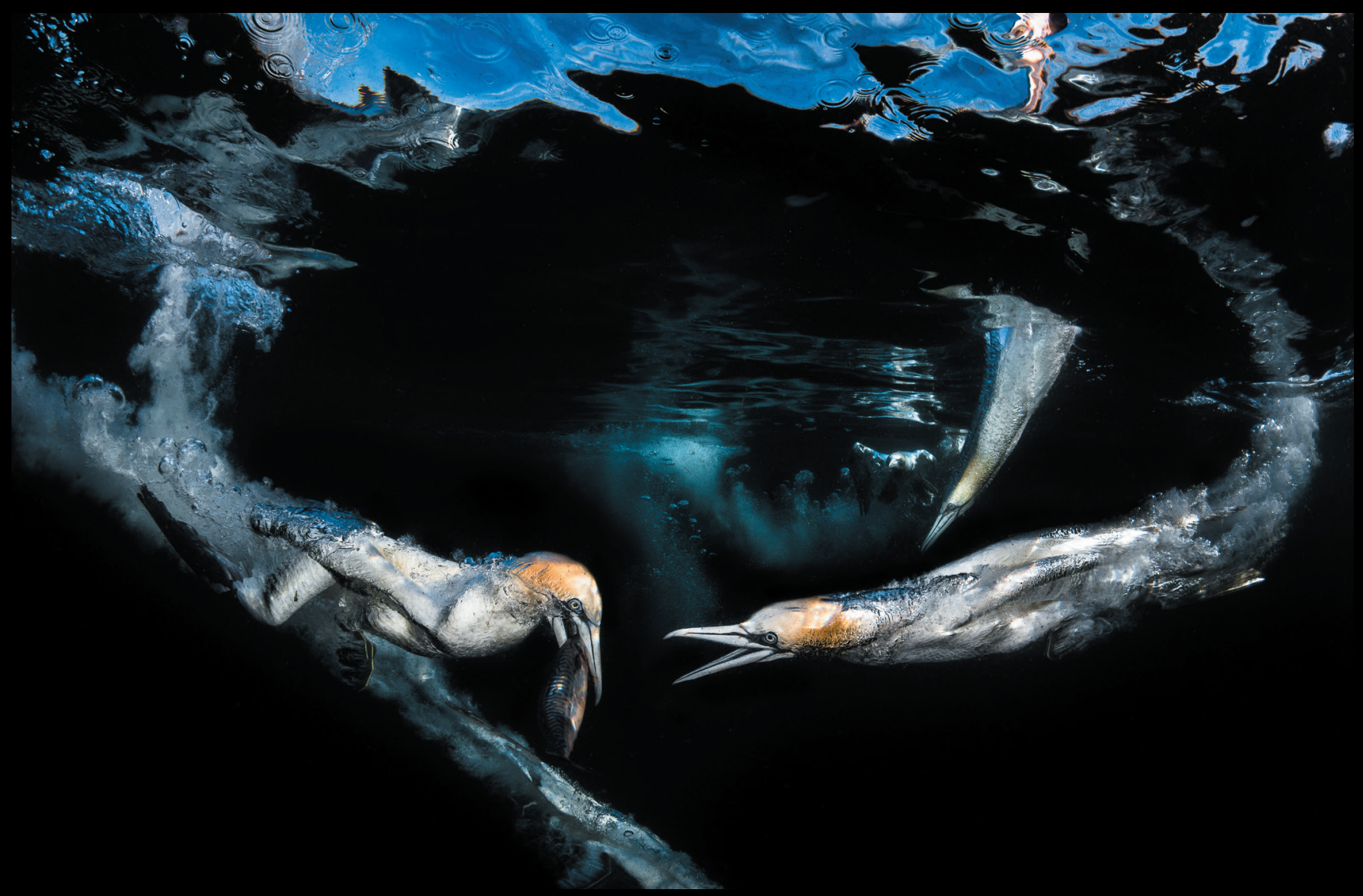

\section{DEEP DIVE}

Gannets in Scottish waters dive to hunt for mackerel and other fish. The birds drop from a height of 30 metres, achieving speeds of 100 kilometres per hour. The image won third place in the behaviour category of the Underwater Photographer of the Year Competition. 